\title{
Serum osteocalcin and vitamin D metabolites in patients with ankylosing spondylitis
}

\author{
H Franck, E Keck
}

\begin{abstract}
Objectives-Osteocalcin is the major non-collagenous protein of bone and is regarded as a specific index of bone formation. The aim of this study was to examine the rate of bone formation measured by osteocalcin in 38 patients with ankylosing spondylitis (AS) and its dependence on various parameters of calcium and phosphate metabolism.

Methods-Serum osteocalcin, alkaline phosphatase, parathyroid hormone, and 1,25-dihydroxyvitamin $D$ were measured in 38 patients with ankylosing spondylitis and in 52 controls.
\end{abstract}

Results-Mean serum osteocalcin was significantly reduced in patients with AS (men 1.7 (1.1) $\mathrm{ng} / \mathrm{ml}$; women $1.2(1.1)$ $\mathrm{ng} / \mathrm{ml}$ ) compared with the corresponding control groups (men $3.2(1.3) \mathrm{ng} / \mathrm{ml}$; women $4 \cdot 1(1 \cdot 7) \mathrm{ng} / \mathrm{ml})$. In contrast, alkaline phosphatase was only slightly but significantly higher (135 (44) U/1) in patients with AS than in the corresponding controls (114 (35) U/1). Serum parathyroid hormone (AS 3.1 (0.7) $v 2.7(0.6) \mathrm{mE} / \mathrm{ml})$ and 1,25-dihydroxyvitamin D (AS 64.0 $(34.5) v 52.4(6.7) \mathrm{pg} / \mathrm{ml})$ were slightly but not significantly higher in patients with AS. Consequently, as both hormones are known to stimulate osteocalcin synthesis, they are not responsible for low osteocalcin levels in patients with AS. No significant correlation between alkaline phosphatase and osteocalcin was found. Low serum levels of osteocalcin in patients with AS reflect lower osteoblastic activity in AS.

Conclusions-Bone turnover in patients with AS is characterised by low bone formation in the presence of normal levels of calcium regulating hormones.

(Ann Rheum Dis 1993; 52: 343-346)

Clinic Mayenbad, Badstrasse 14, 7967 Bad-Waldsee, Germany H Franck

Department of Rheumatology II, Wiesbaden, Germany E Keck

Correspondence to: Dr Franck.

Accepted for publication 18 January 1993 genesis of this osteopenia already seen in early $\mathrm{AS}^{5}$ is controversial ${ }^{35}$ and few data exist on bone turnover. ${ }^{6}$ Alkaline phosphatase, hydroxyproline, and other collagen related substances have been widely used as biochemical markers for bone metabolism.
Although they have been useful in measuring bone turnover, they also have significant limitations. ${ }^{78} \gamma$-Carboxyglutamic acid containing protein of bone, the most abundant protein of bone derived from osteoblasts, ${ }^{9}$ is a specific marker of bone formation. The synthesis of this protein, usually called osteocalcin, is regulated by calciotropic hormones. ${ }^{1011} \mathrm{In}$ particular, 1,25-dihydroxyvitamin D stimulates the production of osteocalcin in osteoblasts. ${ }^{10}$ The aim of this study was to examine the rate of bone formation (measured by the amount of osteocalcin) in patients with AS and its dependence on various parameters of calcium phosphate metabolism, especially parathyroid hormone and 1,25-dihydroxyvitamin $\mathrm{D}$.

\section{Patients and methods}

The study group consisted of an unselected group of 38 consecutive patients with mild to moderate AS (13 women and 25 men, mean ages 37 and 42 years respectively) attending an outpatient clinic for rheumatic disease. The control group (23 women and 29 men aged between 20 and 64 with a mean (SD) age of $37(14.6)$ and $41.6(17)$ years respectively) had no evidence of calcium or skeletal abnormalities by routine history, physical, and biochemical evaluation. Patients with AS had characteristic physical signs and radiographic features according to New York clinical criteria. ${ }^{12}$ None of the patients received glucocorticoids and only two received non-steroidal anti-inflammatory drugs (NSAIDs).

For all subjects and patients blood samples were collected in the morning ( $8 \mathrm{am})$ after an overnight fast. Serum samples were separated by centrifugation and then frozen at $-40^{\circ} \mathrm{C}$.

Osteocalcin was measured in duplicate by a commercial radioimmunoassay (ImmunoNuclear Corporation, Stillwater, MN, USA) by the method of Price and Nishimoto using purified calf bone GLA protein. ${ }^{13}$ The sensitivity of the assay was $0.2 \mathrm{ng} / \mathrm{ml}$ and the concentration could be determined in all patients. In all cases the intraassay variation was less than $8 \%$ and the interassay variation was less than $12 \%$. Parathyroid hormone was determined by a commercial radioimmunoassay (Fleurus, Belgium) using chicken antibody raised against human parathyroid hormone (c terminal). The interassay variation was less than $13 \%$. 25-Hydroxyvitamin $D$, 24,25-dihydroxyvitamin D, and 1,25dihydroxyvitamin $\mathrm{D}$ were determined as described elsewhere. ${ }^{14}$ 
Serum calcium was determined by atomic absorption spectrometry; phosphate, creatinine, and alkaline phosphatase were measured using an autoanalyser. For the erythrocyte sedimentation rate (ESR) measurement, Westergren's method was used.

All results are expressed as mean (SD) values. Comparisons for significance were made using Student's $t$ test. The correlation was calculated according to the method of Dixon and Massey. ${ }^{15}$

\section{Results}

Patients with AS presented with significantly $(\mathrm{p}<0.01)$ lower mean serum osteocalcin levels (men $1 \cdot 7(1 \cdot 1) \mathrm{ng} / \mathrm{ml}$; women $1 \cdot 2(1 \cdot 1) \mathrm{ng} / \mathrm{ml}$ ) than the corresponding control group (men $3 \cdot 2$ $(1 \cdot 3) \mathrm{ng} / \mathrm{ml}$; women $4 \cdot 1(1 \cdot 7)$; fig 1$)$. In contrast, alkaline phosphatase was only slightly, but significantly, higher (135 (44) U/l; $\mathrm{p}<0.025)$ in patients with AS than in the control group (114 (35) U/l) (fig 2). Consequently, no significant correlation $(r=0 \cdot 47$; $\mathrm{p}>0.05)$ between alkaline phosphatase and osteocalcin was found. No increased liver enzymes could be found in the five patients with increased alkaline phosphatase levels. Serum parathyroid hormone values were slightly but not significantly $(p>0.05)$ higher than the controls (AS $3 \cdot 1(0 \cdot 7) \mathrm{mE} / \mathrm{ml}$; control $2 \cdot 7(0.6) \mathrm{mE} / \mathrm{ml}$ ) (fig 3). Mean vitamin D metabolite concentrations (table, fig 4 ) and all serum calcium, phosphate and creatinine values were in the normal range. The concentration of 1,25-dihydroxyvitamin $\mathrm{D}_{3}$ was in the upper limit of the normal range, but significantly different from the controls. The ESR was not increased except for two of the patients receiving NSAIDs. Their laboratory parameters did not differ significantly from the rest of the studied group.

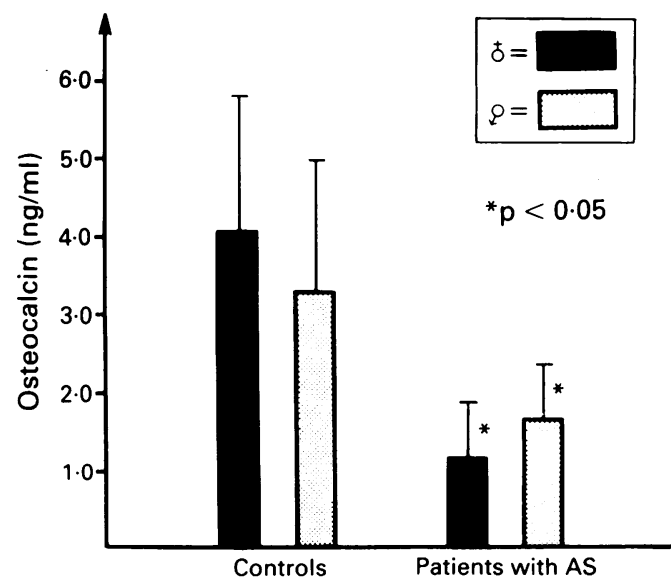

Figure 1 Serum osteocalcin in patients with ankylosing spondylitis $(A S)$.

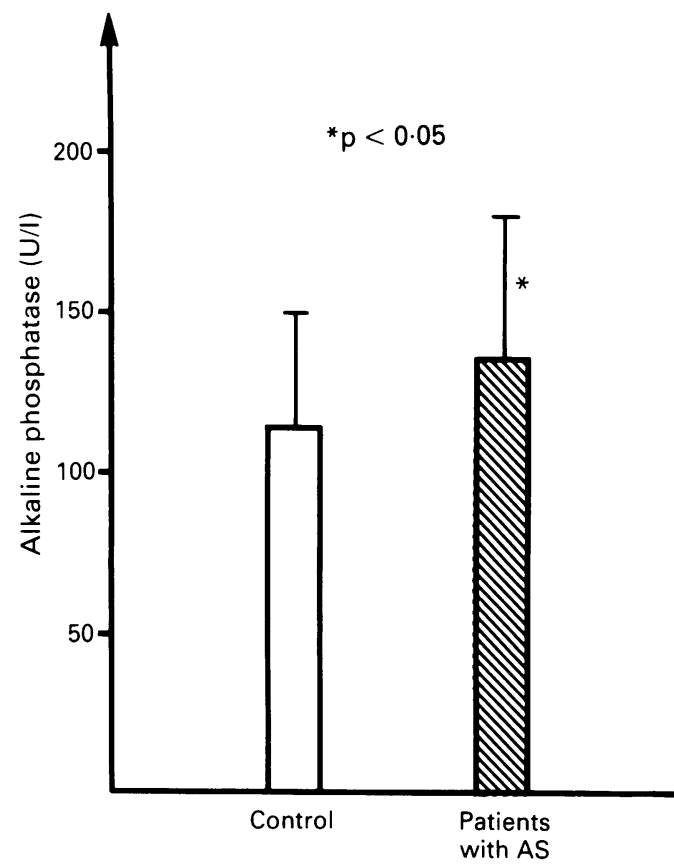

Figure 2 Alkaline phosphatase in patients with ankylosing spondylitis $(A S)$.

\section{Discussion}

Our results reflect a significant reduction of bone formation in patients with AS measured by low serum osteocalcin levels. Serum osteocalcin concentrations are decreased in clinical situations characterised by decreased bone turnover as low turnover osteoporosis. ${ }^{16}$ Patients receiving glucocorticoids ${ }^{17}$ in

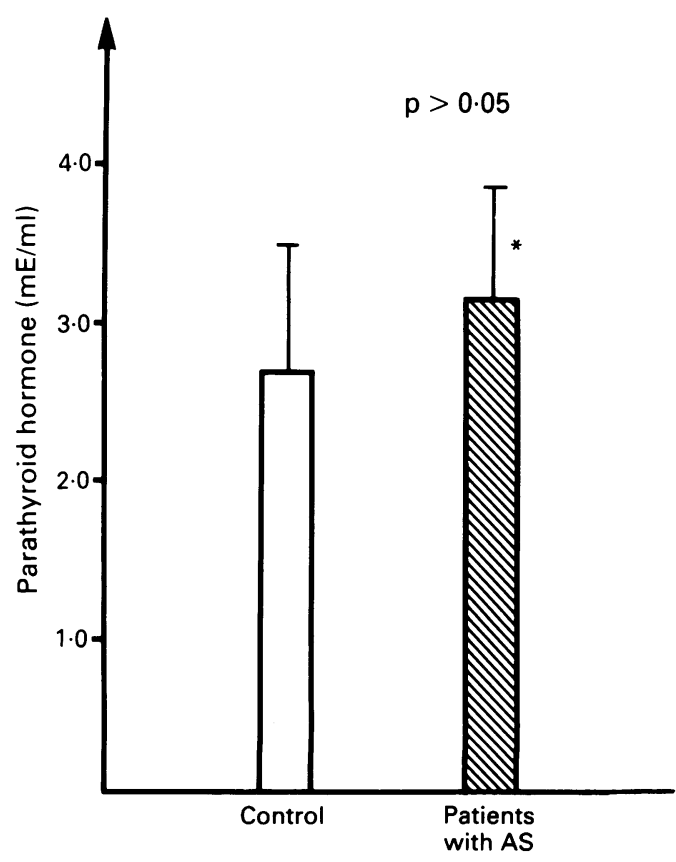

Figure 3 Parathyroid hormone in patients with ankylosing spondylitis (AS).

\begin{tabular}{llll}
\hline & $\begin{array}{l}25-\text { Hydroxyvitamin } D \\
(\mathrm{ng} / \mathrm{ml})\end{array}$ & $\begin{array}{l}24,25-\text { Dihydroxyvitamin } D_{3} \\
(\mathrm{ng} / \mathrm{ml})\end{array}$ & $\begin{array}{l}1,25-\text { Dihydroxyvitamin } D \\
(\mathrm{pg} / \mathrm{ml})\end{array}$ \\
\hline Normal adults & $20 \cdot 1(3 \cdot 2)$ & $2 \cdot 5(0 \cdot 6)$ & $52 \cdot 4(6 \cdot 7)$ \\
Patients with spondylosing arthritis & $21 \cdot 6(13 \cdot 5)$ & $2 \cdot 3(1 \cdot 7)$ & $64 \cdot 0(34 \cdot 5)$ \\
\hline
\end{tabular}




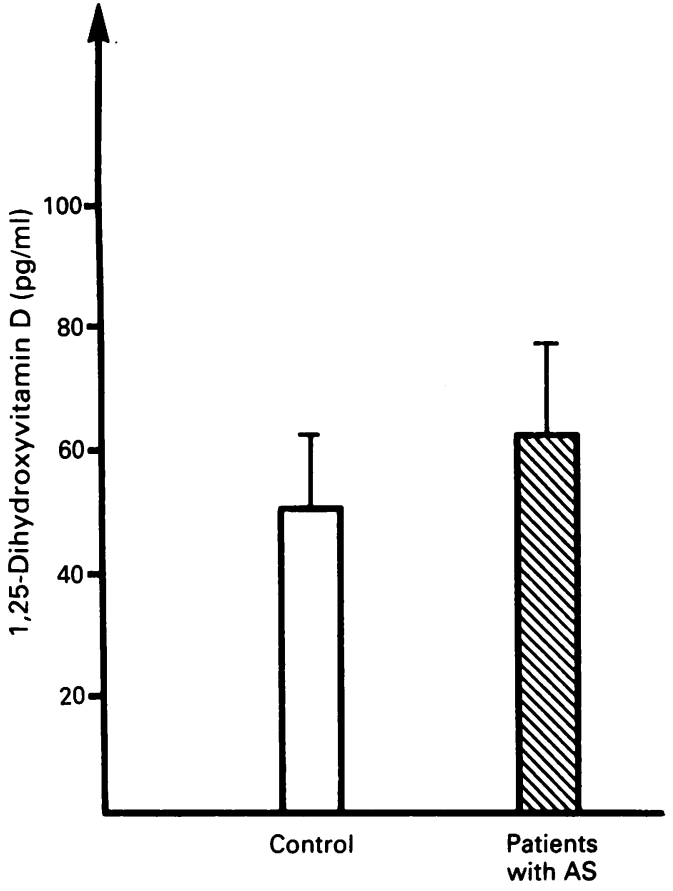

Figure 4 1,25-Dihydroxyvitamin $D$ in patients with ankylosing spondylitis ( $A S)$.

particular show low levels of osteocalcin. None of our patients received glucocorticoids, however.

Reduced synthesis or increased degradation of osteocalcin does not seem to result from the effect of chronic disease on osteoblastic activity as normal circulating osteocalcin levels have been reported in a variety of chronic diseases of non-inflammatory origin. ${ }^{19}$ Reduced circulating levels of osteocalcin have also been measured in other inflammatory arthritides, however. ${ }^{20} 21$ Ekenstam et al showed a significant reduction in circulating levels of serum osteocalcin in patients with seronegative spondyloarthropathy, but only nine of 23 patients had $\mathrm{AS}^{20}$

Alkaline phosphatase is reported to be increased in some patients $(17 \%)$ with $\mathrm{AS},{ }^{22}$ but was not related to increased bone fractions of alkaline phosphatase isoenzyme. A dissociation of alkaline phosphatase and osteocalcin as found in our patients with AS has also been reported by others. ${ }^{19}{ }^{23-25}$ It can be the result of a major hepatic fraction of alkaline phosphatase isoenzyme as reported by Sheehan et $a l^{22}$ We could not find increased $\gamma$ glutamyl transpeptidases in the five patients with increased alkaline phosphatase, however. Laboratory values of the two patients receiving NSAIDs did not differ significantly from the rest of the studied group, except for an increased ESR. In contrast with osteocalcin, alkaline phosphatase does not seem to be a sensitive parameter of bone turnover in patients with AS.

According to our data changes in calcium phosphate metabolism in patients with AS are due to decreased bone formation (measured by low serum osteocalcin) as found in other diseases with osteopenia such as low turnover osteoporosis, ${ }^{16}$ rheumatoid arthritis, and other inflammatory arthritides. ${ }^{20} 21$ The synthesis of osteocalcin can be altered by different states of parathyroid hormone ${ }^{23}$ secretion. Price et $a l^{26}$ showed low osteocalcin levels in patients with hypoparathyroidism. In contrast, levels of parathyroid hormone in our patients were at the upper limit of normal values. Consequently, serum 1,25-dihydroxyvitamin $D_{3}$, the synthesis of which is stimulated by parathyroid hormone, was slightly but not significantly $(p>0.05)$ increased. Although serum calcium and phosphate levels were in the normal range, it is conceivable that low bone formation leads to a net loss of calcium, being compensated for by a slight increase of parathyroid hormone (as discussed in osteoporosis type II) and 1,25-dihydroxyvitamin D in some patients with AS. Our studies show, however, that these two calciotropic hormones, which have a stimulating influence on osteocalcin synthesis, are not responsible for low levels of osteocalcin as they are in the upper limit of the normal range in patients with AS.

Our results indicate that bone turnover in patients with AS is characterised by low bone formation in the presence of normal levels of calcium regulating hormones.

1 Hanson C A, Shagrin J W, Duncan H. Vertebral osteoporosis in ankylosing spondylitis. Clin Orthop 1971; 74: 59.

2 Patton J T. Differential diagnosis of inflammatory spondylitis. Skeletal Radiol 1976; I: 77.

3 Ralston S R, Urquhart G D K, Brezeski M, Sturrock R. Prevalence of vertebral compression fractures due to Prevalence of vertebral compression fractures due to osteopor

4 Reid D, Jermy J, Norman S J, et al. Bone mass in ankylosing spondylitis. $\mathcal{F}$ Rheumatol 1986; 13: 932.

5 Will R, Palmer R, Bhalla A K, Ring F. Osteoporosis in early ankylosing spondylitis: a primary pathological event. Lancet 1989; ii: 1483-7.

6 Kendall M J, Lawrence D S, Shuttleworth G R. Haematology and biochemistry of spondylosing arthritis. $B M F$ 1973; ii: 235 .

7 Kivorikko K I. Excretion of urinary hydroxyproline. In: Frame B, Potts J T, eds. Clinical disorders of bone and Frame B, Potts J T, eds. Clinical disorders of bone and mineral 105.

8 Whyte P M. Alkaline phosphatase and the measurement of bone formation. In: Frame B, Potts J T, eds. Clinical disorders of bone and mineral metabolism. Amsterdam: Excerpta Medica, 1983: 120

9 Price P A, Williamson K M, Lothringer J W. Origin of the vitamin $\mathrm{K}$-dependent bone protein found in plasma and its clearance by kidney and bone. $\mathcal{F}$ Biol Chem 1981; 256: $127-60$.

10 Price P A, Baukol S A. 1.25-dihydroxyvitamin D3 increases synthesis of the vitamin K-dependent bone protein by synthesis of the vitamin K-dependent bone protein
osteosarcoma cells. $\mathcal{F}$ Biol Chem 1980; 255: 316-60.

11 Beresford J N, Gallagher J A, Poser J W, Russell R G G. Production of osteocalcin by human bone cells in vitro. Effects of $1.25(\mathrm{OH}) 2 \mathrm{D} 3,24,25(\mathrm{OH}) 2 \mathrm{D} 3$, parathyroid hormone and glucocorticoids. Metabolic Bone Disease and Related Research 1984; 5: 229-34.

12 Moll J M H, Wight V. New York clinical criteria for ankylosing spondylitis. Ann Rheum Dis 1974; 32: 343.

13 Price P A, Nishimoto S A. Radioimmunoassay for the vitamin $\mathrm{K}$-dependent protein of bone and its discovery in vitamin K-dependent protein of bone and its discover
plasma. Proc Natl Acad Sci USA 1980; 77: 2234-8.

plasma. Proc Natl Acad Sci USA 1980; 77: 2234-8.
14 Keck E, Krüskemper H L, Lilienfeld-Toal v H. Protein binding assays for 25-hydroxycholecalciferol, 24.25-dihydroxycholecalciferol and 1.25-dihydroxycholecalciferol in human plasma. F Clin Chem Clin Biochem 1981; 19: 1043

15 Dixon W J, Massey F J Jr. Introduction to statistical analysis. 3rd ed. New York; McGraw-Hill, 1969.

16 Delmas P D, Brown J P, Malaval L, Edourd C, Meunier $P$ J. Serum bone Gla-protein (BGP) compared to bone histomorphometry in postmenopausal osteoporosis. Serum BGP can predict histological heterogeneity. In:
Cohn D V et al, eds. Endocrine control of bone and calcium Cohn D V et al, eds. Endocrine control of bone
metabolism. Amsterdam: Elsevier, 1984: 73 .

17 Lukert B P, Higgins J C, Stoskopf M M. Serum osteocalcin is increased in patients with hyperthyroidism and decreased in patients receiving glucocorticoids. F Clin Endocrinol Metab 1986; 62: 1056-8.

18 Reid I R, Chapman G E, Fraser T R C, et al. Low serum osteocalcin levels in glucocorticoid treated asthmatics. $\mathcal{F}$ Clin Endocrinol Metab 1986; 62: 379-83.

19 Slovik D M, Gundberg C M, Neer R M, Lian J B. Clinical evaluation of bone turnover by serum osteocalcin measurements in a hospital setting. F Clin Endocrinol Metab 1984; 59: 228-30. 
20 Ekenstam E A, Sverker L, Hällgen R. Serum osteocalcin in rheumatoid arthritis and other inflammatory arthritides: relation between inflammatory activity and the effect of glucocorticoids and remission inducing drugs. Ann Rheum Dis 1986; 45: 484 .

21 Franck H, van Valen F, Keck E, Krüskemper H L. Osteocalcin und Knochenstoffwechsel bei rheumatoider calcin und Knochenstoffwechsel bei rheumatoider Arthritis

22 Sheehan N J, Slavin B M, Kind P R N, Mathews J A Increased serum alkaline phosphatase activity in ankylosing spondylitis. Ann Rheum Dis 1988; 47: 563-5.
23 Deftos L J, Parthemore J G, Price P A. Changes in plasma bone Gla protein during treatment of bone disease. Calcif Tissue Int 1982; 34: 121

24 Coen G, Mazzaferro S, Bonucci E, et al. Bone GLA protein in predialysis chronic renal failure. Effect of $1.25(\mathrm{OH}) 2 \mathrm{D} 3$ administration in a long-term follow-up. Kidney Int 1985; 28: 783-90.

25 Delmas P D, Wilson D M, Mann K G, Riggs B L. Effect of renal function on plasma levels of bone Gla protein of renal function on plasma levels of bone

26 Price P A, Parthemore J G, Deftos L J. New biochemical marker for bone metabolism. I Clin Invest 1980; 66: 878-83. 